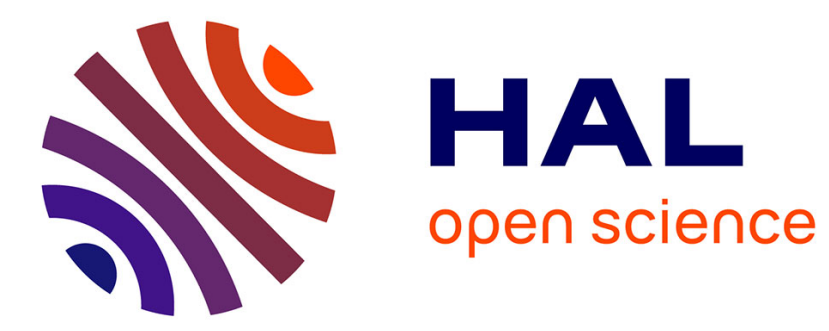

\title{
A predictive model to reflect the final stage of spark plasma sintering of submicronic $\alpha$-alumina
}

Charles Manière, Lise Durand, Alicia Weibel, Claude Estournès

\section{To cite this version:}

Charles Manière, Lise Durand, Alicia Weibel, Claude Estournès. A predictive model to reflect the final stage of spark plasma sintering of submicronic $\alpha$-alumina. Ceramics International, 2016, vol. 42 $\left(\mathrm{n}^{\circ} 7\right)$, pp. 9274-9277. 10.1016/j.ceramint.2016.02.048 . hal-01486921

\section{HAL Id: hal-01486921 https://hal.science/hal-01486921}

Submitted on 10 Mar 2017

HAL is a multi-disciplinary open access archive for the deposit and dissemination of scientific research documents, whether they are published or not. The documents may come from teaching and research institutions in France or abroad, or from public or private research centers.
L'archive ouverte pluridisciplinaire HAL, est destinée au dépôt et à la diffusion de documents scientifiques de niveau recherche, publiés ou non, émanant des établissements d'enseignement et de recherche français ou étrangers, des laboratoires publics ou privés. 


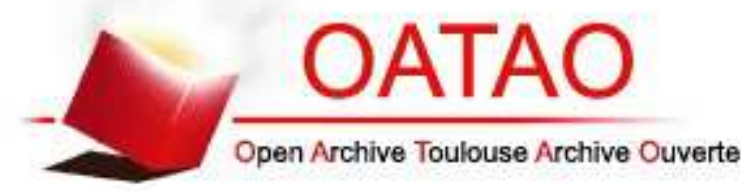

\section{Open Archive TOULOUSE Archive Ouverte (OATAO)}

OATAO is an open access repository that collects the work of Toulouse researchers and makes it freely available over the web where possible.

This is an author-deposited version published in : http://oatao.univ-toulouse.fr/ Eprints ID : 16741

To link to this article : DOI:10.1016/j.ceramint.2016.02.048

URL : http://dx.doi.org/10.1016/j.ceramint.2016.02.048

To cite this version : Manière, Charles and Durand, Lise and Weibel, Alicia and Estournès, Claude A predictive model to reflect the final stage of spark plasma sintering of submicronic $\alpha$-alumina. (2016) Ceramics International, vol. 42 ( $\left.{ }^{\circ} 7\right)$. pp. 9274-9277. ISSN $0272-8842$

Any correspondence concerning this service should be sent to the repository administrator: staff-oatao@ listes-diff.inp-toulouse.fr 


\title{
A predictive model to reflect the final stage of spark plasma sintering of submicronic $\alpha$-alumina
}

\author{
Charles Manière ${ }^{\mathrm{a}, \mathrm{b}, \mathrm{c}}$, Lise Durand ${ }^{\mathrm{b}}$, Alicia Weibel ${ }^{\mathrm{a}}$, Claude Estournès ${ }^{\mathrm{a}, \mathrm{c}, *}$ \\ a Université de Toulouse, Institut Carnot Cirimat, UMR 5085 CNRS, Université Toulouse III Paul-Sabatier-INPT, 118 Route de Narbonne, 31062 Toulouse \\ Cedex 9, France \\ ${ }^{\mathrm{b}}$ CNRS, CEMES, UPR 8011 and Université de Toulouse, 29 Rue Jeanne Marvig, 31055 Toulouse, France \\ ' CNRS, Institut Carnot CIRIMAT, 118 Route de Narbonne, 31602 Toulouse Cedex 9, France
}

\begin{abstract}
A B S T R A C T
The grain growth/densification interaction is known to strongly decrease the shrinkage rate during the final stages of sintering. This phenomenon was studied for $\alpha$-alumina to provide more accurate sintering models for ceramics. Isothermal interrupted experiments were conducted to identify the parameters of the grain growth law for the model.
\end{abstract}

Keywords:

Spark plasma sintering

Modeling

Grain growth

Densification

In both pressureless and pressurized sintering processes, like Hot Pressing (HP) and Spark Plasma Sintering (SPS), the grain size is known to have a strong influence on the final stage of sintering. According to Rahaman [1], the attainment of high relative density requires minimization of the grain growth phenomenon. For example, transparent alumina ceramics (porosity lower than $0.1 \%$ ) were obtained at low temperature or low heating rate [2,3], which allows densification without grain growth. These results can be explained considering the grain size dependence of the diffusion creep mechanisms, Nabarro-Herring (lattice diffusion) $[4,5]$ and Coble (grain boundary diffusion) [6]. In both of them, the displacement is due to atomic motion over varying distances depending on the grain size. The larger the grain, the lower the creep rate, because the atomic diffusion distances increase. Thus, in both lattice and grain boundary diffusion creep, the grain size term appears in the denominator of the creep rate equation:

$\dot{\varepsilon}_{c}=\frac{C D \sigma^{n}}{G^{m} k T}$

where $\dot{\varepsilon}_{c}$ is the creep rate, $C$ a constant, $\sigma$ the stress, $D$ the diffusion coefficient, $k$ the Boltzmann constant, $G$ the grain size, $T$ the absolute temperature, $m$ and $\mathrm{n}$ the grain size and stress exponent, respectively.

In this expression, the creep law appears to be strongly influenced by the grain size exponent. Nabarro and Herring [4,5]

\footnotetext{
* Corresponding author at: CNRS, Institut Carnot CIRIMAT, 118 Route de Narbonne, 31602 Toulouse Cedex 9, France.
}

determined, for lattice diffusion creep, a value for the grain size exponent $m=2$. On the other hand, Coble [6] established a grain size exponent $m=3$ for grain boundary diffusion creep. Consequently, the determination of the $m$ exponent allows the identification of the diffusional creep mechanism. Most widespread sintering models are built on porous creep behavior law, such as Olevsky's sintering model $[7,8]$ for which the creep law is coupled to a grain growth law.

In a previous publication [9] on SPS densification modeling of a pure submicronic $\alpha$-alumina powder, we showed that taking into account the grain growth phenomenon allows correction of the relative density values at the final stage of sintering. We showed that, by inverse analysis, it is possible to determine an approximate parameter for the grain growth law using the experimental data obtained at the final stage of sintering. Thus, using this value, the model obtained appears to be reliable since the final average grain diameter calculated is in good agreement with the experimentally observed one. Moreover, the sintering laws identified in various pressure and heating rate conditions converged to a linear $(n=1)$ creep behavior. A result similar to that reported by Langer et al. [10] on the same alumina powder.

The aim of the present work is to determine the parameters of the alumina grain growth law by isothermal interrupted tests and to compare the values obtained to those estimated by reverse analysis of our previous study. The other objective is to discuss the grain growth mechanisms and to study the densification/grain growth interaction during the final stage of sintering in the SPS process. 
The sintering experiments were conducted on the Dr. Sinter 2080 SPS machine (SPS Syntex INC JapanCo. Ltd., Japan) of the Plateforme Nationale CNRS de Frittage Flash located at the Université Toulouse III-Paul Sabatier in Toulouse. For each experiment, $1 \mathrm{~g}$ of powder ( $\alpha$-alumina $99.99 \%$, reference TM-DAR, Taimei Chemicals Co. Ltd, median particle size $0.14 \mu \mathrm{m}$ ) was introduced and consolidated within an $8 \mathrm{~mm}$ inner diameter graphite die. Each experiment was performed under vacuum $(<10 \mathrm{~Pa})$ with a pulse sequence of $12-2$ (12 pulses and 2 dead times, each pulse and dead time having a duration of $3.3 \mathrm{~ms}$ ). For easy removal of the sample graphite foil (e.g. Papyex from Mersen) was introduced at the sample/die and sample/punch interfaces. The heating rate was $100 \mathrm{~K} / \mathrm{min}$. The pressure was kept constant at $100 \mathrm{MPa}$ during the whole cycle. In order to identify all the terms of the grain growth law, isothermal tests were performed at three programmed temperatures $\left(1100{ }^{\circ} \mathrm{C}, 1200^{\circ} \mathrm{C}\right.$ and $\left.1300^{\circ} \mathrm{C}\right)$ and with different dwell times $(0,1,5$ and $15 \mathrm{~min})$. The real temperature of the sample was determined in other experiments, performed in similar conditions, with a sacrificial thermocouple located in the powder bed. An empiric function obtained by calibrating the two temperatures at the beginning of the sintering cycle was used to extrapolate the temperature of the dwell to respectively 1305 , 1439 and $1575{ }^{\circ} \mathrm{C}$. The huge differences between setpoint and extrapolated sample temperatures observed are explained by a high thermal contact resistance present at the punch/die and sample/die interfaces. In previous studies (C. Arnaud et al. [11], C. Manière et al. [12]) these temperature differences where confirmed by thermal images taken during experiments performed with an open die. The fracture surfaces of the pellets were observed by field emission-gun scanning electron microscopy (FESEM, JEOL JSM 6700 F). FESEM images of the fracture surfaces of the sintered materials are presented in Fig. 1. Based on the work of Horovistiz et al. [13] the average grain size was determined from such fracture images considering about a hundred grains. The Mendelson [14] stereological factor of 1.56 was used to transform the 2D average intercept length into 3D average grain size. Associated standard deviation (Table 1) represents the grain size distribution, the error on the determination of the grain size is $\pm 0.05 \mu \mathrm{m}$. As expected, grain size depends much more on the temperature than on the dwell time (Table 1). It is to be noted that there is a very high standard deviation at high temperatures $\left(1439{ }^{\circ} \mathrm{C}\right.$ and $1575^{\circ} \mathrm{C}$ ) which is due to the presence of the small grains.

The analytic Olevsky's sintering model $[7,8]$ for uni-axial die compaction can be summarized by Eq. (2):

$$
\frac{\dot{\rho}}{\rho}=\left(\frac{\left|\sigma_{z}\right|}{K(T, G)\left(\psi+\frac{2}{3} \varphi\right)^{1+\frac{1-n}{2 n}}(\rho)^{\frac{n-1}{2 n}}}\right)^{n}
$$

where $\dot{\rho}$ is the densification rate, $\rho$ is the relative density, $\sigma_{z}$ the applied stress, $\varphi$ and $\psi$ the shear and bulk moduli, $K(T, G)$ the creep consistency factor depending on the grain size $G$ and the temperature $T$, and the stress exponent $n$.

Based on our previous work [9] the expression of the consistency factor is:

$$
\left.K(T, G)=\left(\frac{G}{G_{0}}\right)^{2} \frac{1}{A_{o}^{\frac{1}{n}}} T^{1} \frac{\exp }{(n R T}\right)
$$

Where $G_{0}$ is the initial grain diameter, $A_{0}$ a constant of

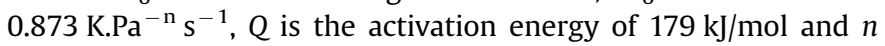
the stress exponent equal to 1 [9].

The grain growth law mainly depends on the temperature [1] but may also depends on both the applied pressure $(P)$ [15-17] and the relative density $(\rho)$ [18]. As we will see later, the grain growth model considered, which does not take into account any pressure or porosity dependence, gives good agreement with experiment, therefore in our experimental domain these dependences $(P$ and $\rho$ ) can be ignored. In the present study, expression (4) $[19,20]$

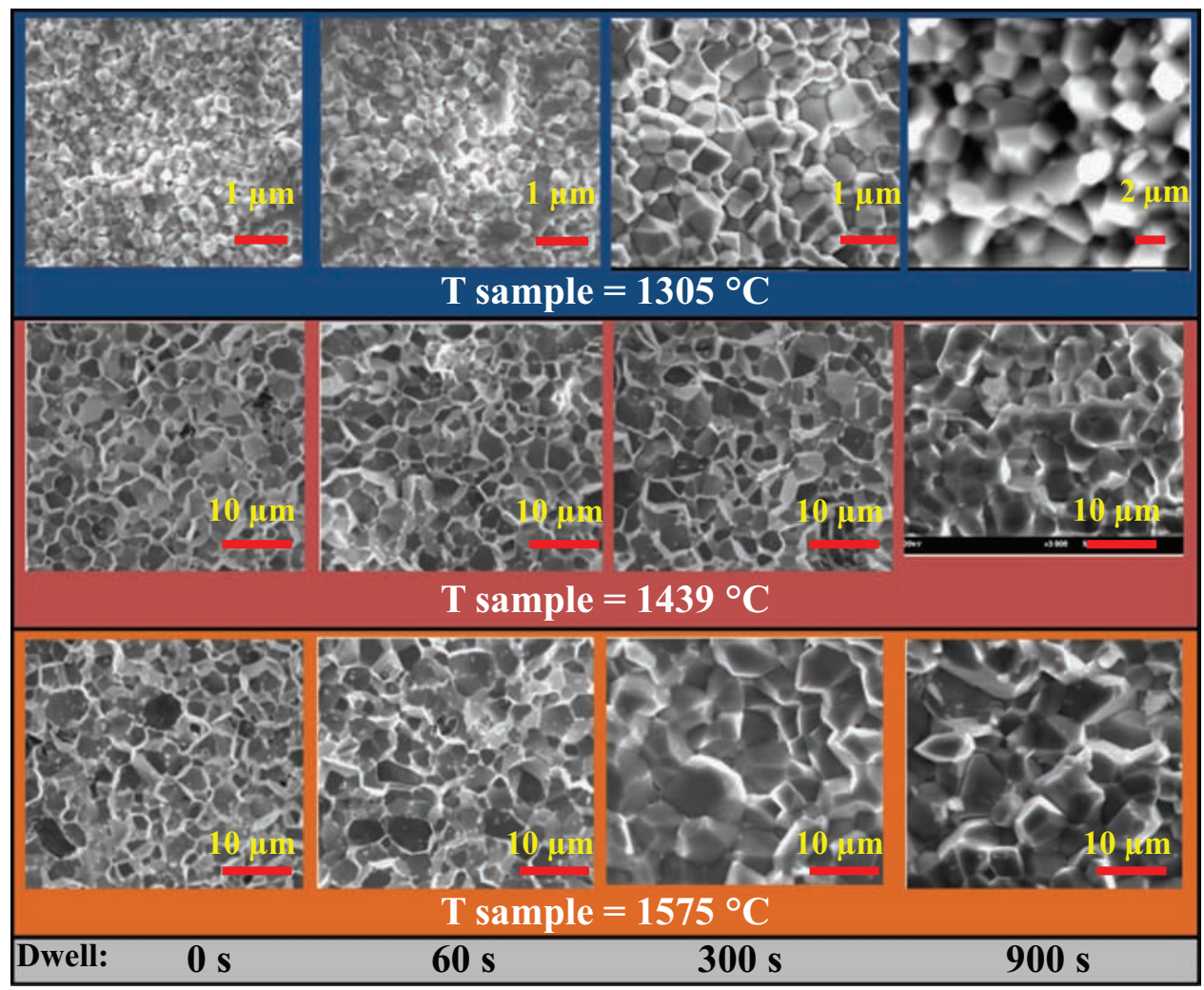

Fig. 1. FESEM images of the fracture surfaces of the materials sintered at different temperatures and dwell times. 
Table1

Average grain size, standard deviation and relative density for the different temperatures and dwell times.

\begin{tabular}{lllll}
\hline $\begin{array}{l}\text { Dwell tempera- } \\
\text { ture }\left({ }^{\circ} \mathrm{C}\right)\end{array}$ & $\begin{array}{l}\text { Dwell } \\
\text { time }(\mathrm{s})\end{array}$ & $\begin{array}{l}\text { Average grain } \\
\text { size }(\mu \mathrm{m})\end{array}$ & $\begin{array}{l}\text { Standard de- } \\
\text { viation }(\mu \mathrm{m})\end{array}$ & $\begin{array}{l}\text { Relative den- } \\
\text { sity }( \pm 0.5 \%)\end{array}$ \\
\hline \multirow{2}{*}{1305} & 0 & 0.31 & 0.08 & 94.8 \\
& 60 & 0.46 & 0.11 & 99.3 \\
& 300 & 1.08 & 0.29 & 98.6 \\
1439 & 900 & 1.94 & 0.55 & 98.3 \\
& 0 & 4.47 & 1.50 & 97.3 \\
& 60 & 4.95 & 2.18 & 98.2 \\
1575 & 300 & 5.38 & 2.22 & 98.1 \\
& 900 & 5.89 & 2.44 & 98.0 \\
& 0 & 6.06 & 1.49 & 97.9 \\
& 60 & 7.23 & 2.25 & 96.8 \\
& 300 & 8.81 & 2.90 & 96.9 \\
& 900 & 12.07 & 3.77 & 98.6 \\
\hline
\end{tabular}

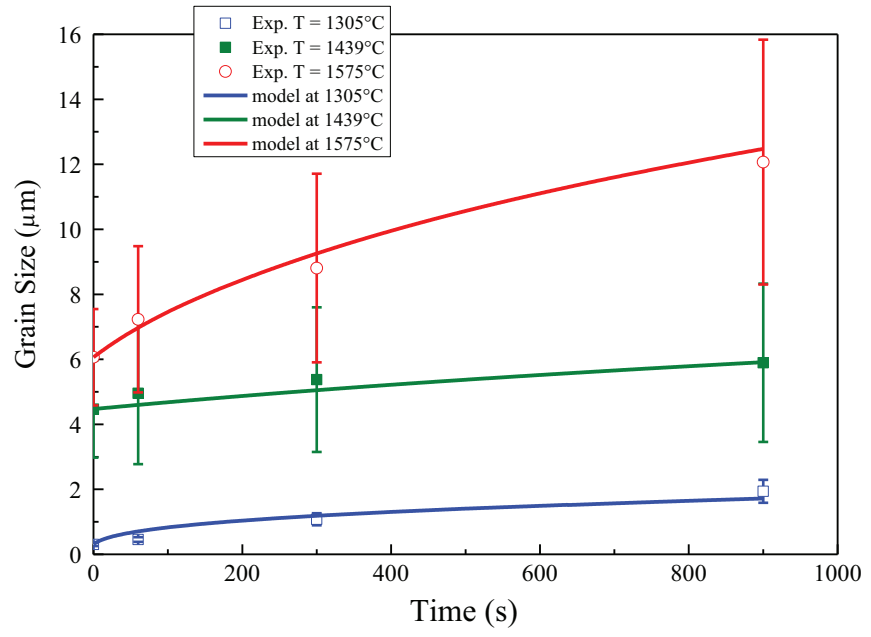

Fig. 2. Model/experimental isothermal plot of grain size versus time.

considered for the grain growth rate $(\dot{G})$ is only temperature dependent:

$$
\dot{G}=\frac{k_{0} \exp \left(\frac{-Q g}{R T}\right)}{G^{m}}
$$

where $k_{0}$ is a constant, $Q_{g}$ the grain growth activation energy and $R$ the gas constant.

Eq. (4) can be transformed into its logarithmic form (Eq. (5)):

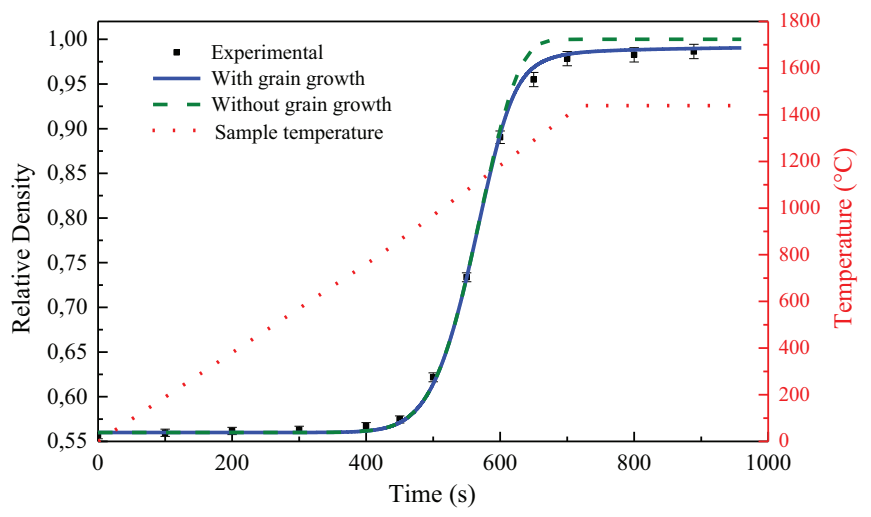

Fig. 4. Sintering model with and without grain growth (heating rate $100 \mathrm{~K} / \mathrm{min}$, $8 \mathrm{~mm}$ diameter sample [9]). (For interpretation of the references to color in this figure, the reader is referred to the web version of this article.).

$\ln (\dot{G})=\ln \left(k_{0}\right)-\frac{Q_{g}}{R} * \frac{1}{T}-m * \ln (G)$

at constant temperature the following term of Eq. (5) is a constant:

$\mathrm{Cst}=\ln \left(k_{0}\right)-\frac{Q_{g}}{R} * \frac{1}{T}$

As there is not enough available data in the grain growth curve to determine $\dot{G}$ we have considered a fit (i.e. the interpolation curves reported in Fig. 2).

All of the linear regressions (Fig. 3) give straight lines which, over the experimental domain explored, validate the temperature dependent grain growth model (4).

The slope of the plot of $\ln (\dot{G})=f(\ln G)$ at a given temperature (Fig. 3a) gives an $m$ exponent ranging from 1.89 to 2.12. Considering Eq. (6) and a m value equal to $2, k_{0}$ constant and activation energy $Q_{g}$ were determined (Fig. $3 b$ ) and are equal to $5.53 \times 10^{-4} \mathrm{~m}^{3} / \mathrm{s}$ and $530 \mathrm{~kJ} / \mathrm{mol}$, respectively.

For pure materials undergoing normal grain growth, an m value equal to 2 corresponds to a grain boundary control mechanism [21]. The grain growth activation energy of $530 \mathrm{~kJ} / \mathrm{mol}$ is in good agreement with that $(520 \mathrm{~kJ} / \mathrm{mol})$ determined in previous works by calibration on the final stage of sintering [9]. Olevsky et al. [7] identified a higher grain growth activation energy ( $570 \mathrm{~kJ} / \mathrm{mol}$ ) for submicronic $\alpha$-alumina probably because of the larger initial grain size of the powder used $(0.38 \mu \mathrm{m} v s 0.14 \mu \mathrm{m})$.

To highlight the effect of grain growth on sintering, the grain growth law parameters were used to model previously published sintering data at $1400{ }^{\circ} \mathrm{C}$ [9]. The result is reported in Fig. 4. The green curve converging at the end of the sintering to a full
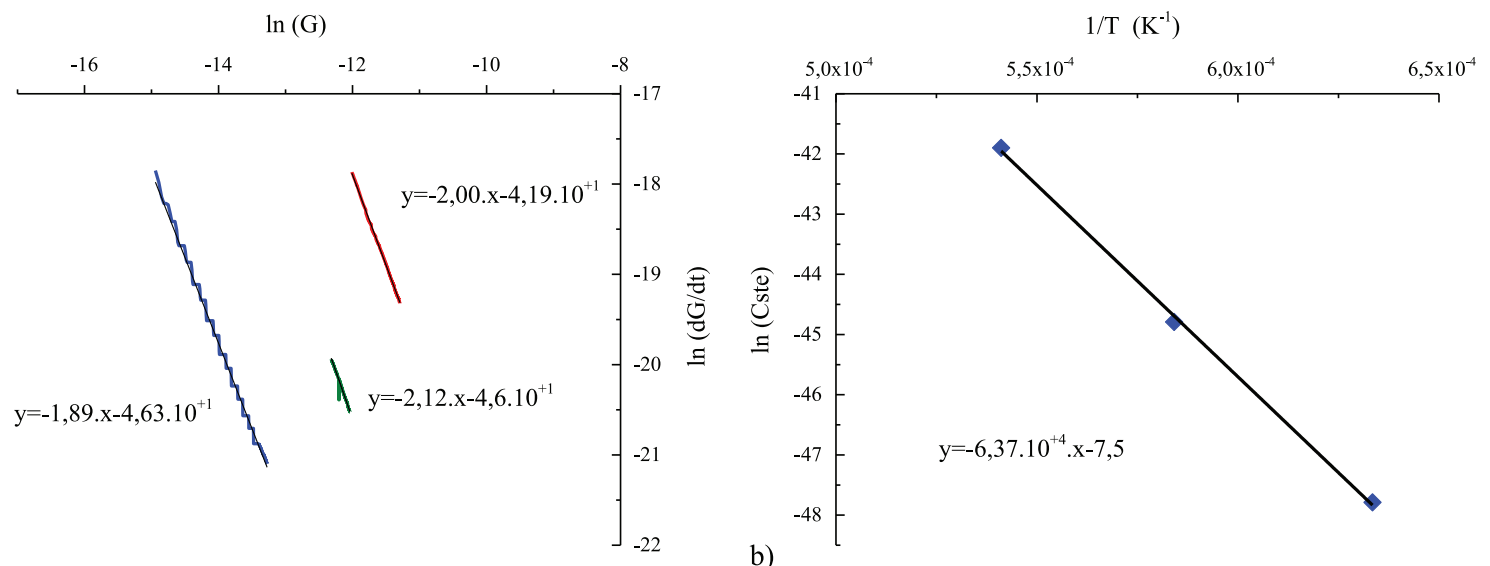

Fig. 3. Grain growth model identification a) determination of the m exponent (b) $k_{0}$ constant and $Q$ determination. 
densification is the one given by the sintering model (Eq. (2)) without taking into account the grain growth law. The blue curve giving a full description of the evolution of the relative density during the final stages of sintering was obtained using the complete sintering model ((Eqs. (2) and (4)) with the grain growth effect.

In conclusion, the grain growth law parameters of a pure submicronic $\alpha$-alumina were determined using isothermal treatments at three temperatures. In the experimental domain considered, the grain growth mechanism suggested by the $m$ exponent is a grain boundary control mechanism. Introducing the parameters obtained in a mechanical model of the sintering process enabled a good description of the relative density curve and in particular of the non-attainment of full densification at the end of the cycle.

\section{Acknowledgments}

Electron microscopy was performed at the "Centre de microcaractérisation Raimond Castaing" - UMS 3623, Toulouse.

\section{References}

[1] M.N. Rahaman, Sintering of Ceramics, CRC Press, Boca Raton, FL, 2008.

[2] B.-N. Kim, K. Hiraga, K. Morita, H. Yoshida, Spark plasma sintering of transparent alumina, Scr. Mater. 57 (2007) 607.

[3] B.-N. Kim, K. Hiraga, K. Morita, H. Yoshida, Effects of heating rate on microstructure and transparency of spark-plasma-sintered alumina, J. Eur. Ceram. Soc. 29 (2009) 323.

[4] F.R.N. Nabarro, Deformation of crystals by the motion of single ions, in: Proceedings of the Int Conf on the Strength of solids, Physical Society London, 1948, pp. 75 .

[5] C. Herring, Diffusional viscosity of a polycristalline solid, J. Appl. Phys. 21 (1950) 437.
[6] R.L. Coble, A model for boundary diffusion controlled creep in polycristalline materials, J. Appl. Phys. 34 (1963) 1679.

[7] E.A. Olevsky, C. Garcia-Cardona, W.L. Bradbury, C.D. Haines, D.G. Martin, D. Kapoor, Fundamental aspects of spark plasma sintering: II. Finite element analysis of scalability, J. Am. Ceram. Soc. 95 (2012) 2414-2422.

[8] E.A. Olevsky, Theory of sintering: from discrete to continuum, Mater. Sci. Eng. R23 (1998) 41-100.

[9] C. Maniere, L. Durand, A. Weibel, C. Estournès, Spark-plasma-sintering and finite element method: from the identification of the sintering parameters of a submicronic $\alpha$-alumina powder to the development of complex shapes, Acta Mater. (2016) 169-175.

[10] J. Langer, M.J. Hoffmann, O. Guillon, Direct comparison between hot pressing and electric field assisted sintering of submicron alumina, Acta Mater. 57 (2009) 5454-5465.

[11] C. Arnaud, C. Manière, G. Chevallier, C. Estournès, R. Mainguy, F. Lecouturier, et al., Dog-bone copper specimens prepared by one-step spark plasma sintering, J. Mater. Sci. 50 (2015) 7364-7373.

[12] C. Manière, A. Pavia, L. Durand, G. Chevallier, K. Afanga, C. Estournès, Finiteelement modeling of the electro-thermal contacts in the spark plasma sintering process, J. Eur. Ceram. Soc. 36 (2016) 741-748.

[13] A.L. Horovistiz, J.R. Frade, L.R.O. Hein, Comparison of fracture surface and plane section analysis for ceramic grain size characterisation, J. Eur. Ceram. Soc. 24 (2004) 619-626.

[14] M.I. Mendelson, Average grain size in polycrystalline ceramics, J. Am. Ceram. Soc. 52 (1969) 443-446.

[15] M. Clark, T. Alden, Deformation enhanced grain growth in a superplastic Sn1\%Bi alloy, Acta Metal. 21 (1973) 1195-1206.

[16] H. Tagai, T. Zisner, High-temperature creep of polycrystalline magnesia: I, effect of simultaneous grain growth, J. Am. Ceram. Soc. 51 (1968) 303-310.

[17] K.R. Venkatachari, R. Raj, Superplastic flow in fine-grained alumina, J. Am. Ceram. Soc. 69 (1986) 135-138.

[18] M.A. Spears, A.G. Evans, Microstructure development during final/ intermediate stage sintering - II. Grain and pore coarsening., Acta Metal. 30 (1982) 1281-1289.

[19] J. Besson, M. Abouaf, Grain growth enhancement in Alumina during hot isostatic pressing, Acta Metall. Mater. 39 (1991) 2225-2234.

[20] H.V. Atkinson, Overview no. 65: theories of normal grain growth in pure single phase systems, Acta Metall. 36 (1988) 469.

[21] D. Bernache-Assollant, M. Soustelle, C. Monty, J.M. Chaix, Chimie-physique du frittage, Hermes (1993). 